مسائل الجملة الفعلية : دراسة نحوية

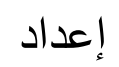

$$
\text { ناهد ابراهيم الامام }
$$

باحثة مسجلة لارجة الماجستير- قسم اللغة العربية وآدابها

كلية الآداب- جامعة بورسعيد 


\section{مستخلص الدراسة:}

تعرض الدراسة بعض المسائل النحوية للجملة الفعلية في الأزمنة المختلفة، وتتناول أقوال النحاة القدامى، فيما يتعلق بكل مسألة من المسائل النحوية التي تخص هذه لأفعال، مع مناقتشة هذه الآراء المختلفة والترجيح بينها في ضوء أداة النحاة. كما توضح الدر اسة أهية الفعل في أزمنته المختلفة، والتي تؤدي إلى دلالات مختلفة في السياق التركيبي للجملة العربية.

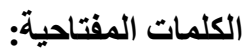

النحاة ـ المسائل ـ بالجملة الفعلية_مناقثاتــ الآراء المختلفة النحوية.

المقدمة

الحمد لله رب العالمين، و الصلاة و السلام على أشرف المرسلين وسلّم تسليمًا كثيرًا ، وبعد،

فإن در اسة الجملة العربية بتعدد أقسامها اسمية وفعلية وما طر أ عليها من تقسميات أخر هى جملة مايهتم به الدرس النحوي، ولعل في دراسة الجملة الفعلية مايضيف إلى الواقع اللغوي أبعادًا في التراكيب العديدة التي نوليها كل الاهتمام ؛ ومن ثم كان البحث الحالي الخاص " مسائل الجملة الفعلية" در اسة نحوية. وقد اعتد البحث الحالي على الدنهج الوصفي في توظيف هذه المسائل؛ بهدف إثراء الدرس النحوي من خلال الأزمنة المختلفة للجملة الفعلية، ولذا تعرض الدراسة بعض المسائل النحوية للجملة الفعلية من خلال كتاب تراثي اهتم بالنص النبوي الثريف، وعالج العناصر الآتية : بعض المسائل التي تخص الفعل الماضي، وكذلك الفعل المضارع، وكذلك الفعل الأمري. وقد تطلب البحث التعرف على أقو ال النحاة القدامفي كل مسألة تخص هذه الأفعال، ومناقتنها، و الترجيح بين الآر اء، والانتصار للر أب في ضوء أدة النحاة. وقد اعتمد البحث البحث على مجمو عة من المر اجع المرتبطة 
بالدر اسة ارتباطًا وثيقًا، وخلص إلى مجمو عة من النتائج المهمة في الدرس النحوي عمومًا، و الجملة الفعلية على وجه الخصوص .

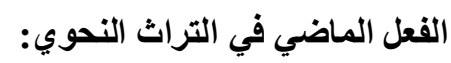
ينقسم الفعل من حيث دلالته على الزمن إلى ثلاثة أقسام: ماض، ومضار ع، و أمر. فالماضي: هو ما وقع في زمان قبل الزمن الذي نحن فيه('). أما المضار ع فهو ما يدل على حدوث شيء في

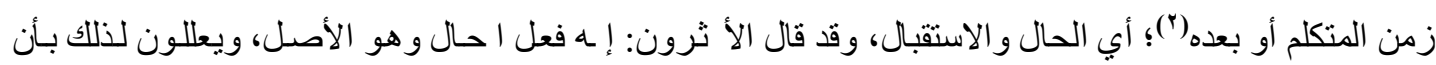
الأصل في الفعل أن يكون خبراً و الأصل في الخبر أن يكون صدقاً، وفعل الحال يمكن الإشـارة إليه، فيتحقق و ـوده فيصدق عنه، و لأن فعل الحال مشار إليه فله حظ من الوجود وا اضـي والمستقبل معدومان ("). أمـا فعل الأمر فهو كلمة تدل بنفسها على أمرين مجتمعين: معنى ووزن، و هذا المعنى يكون مطلوباً في زمن مستقبل، و لا بـد من فعل الأمر أن يدل بنفسه مباثرة على الطلب من غير زيادة على صيغته(؛). ويتسم الفعل الماضي بتاء الفاعل سو اء كانت للمتكلم أو المخاطب أو الغائب، كما يتسم بتاء التنأنيث السـاكنة، واختص لها الاستغناء المضار ع عنها بتاء المضار عة و الماضي بياء المخاطبة، وقد وضحها ابن مالك في قوله:

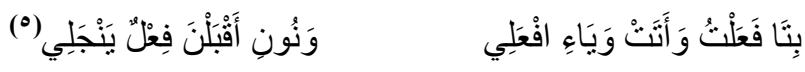

$$
\begin{aligned}
& \text { (') الأشباه والنظائر في النحو: ب/ع ا. }
\end{aligned}
$$

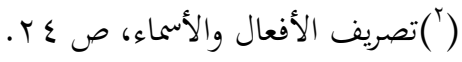

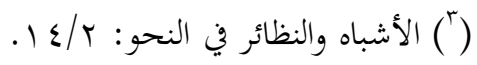

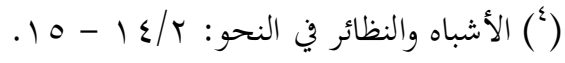

$$
\begin{aligned}
& \text { ( ) شرح ألفية ابن مالك، ص م. }
\end{aligned}
$$


و الفعل الماضـي مبنـي على الفتح كـ(ذهب وضرب)، و علامتهـ تـاء التأنيث السـاكنة، و إذا اتصلت بـه واو الجماعة بني على الضم، وذلك ثل: (ذهبُو ا)، أ إ إذا اتصل بـه ضمبر الرفع ا تحرك بني على اسكون، مثل:

1 - وقوع الفعل الماضي حالا:

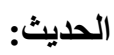

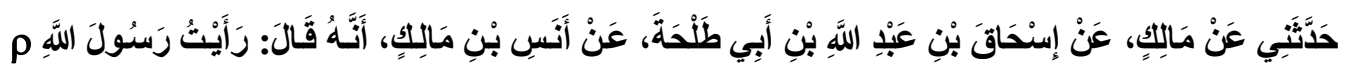

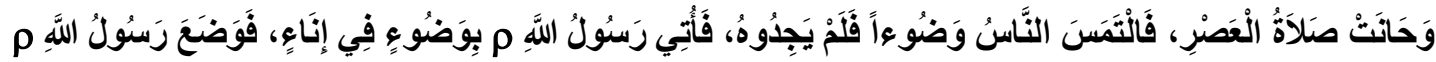

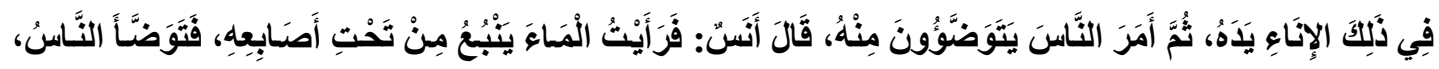

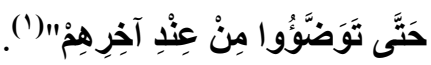
قال ابن البِّيد: قوله: (رأيت رسول الله موحانت صلاة العصر )،و المعنى: (وقد حانت)، و لابد من دير ـ2 ـ هنا - لأن الجملة في موضع الحال، و الماضي لا يصلح أن يكون حالاً إلا أن يكون معه قد مظهرة أو مضمرة(؟).

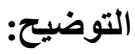

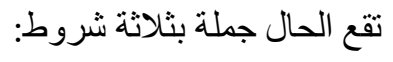

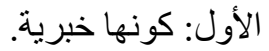

الثاني: أن تكون غير مصدرة بدليل الاستقبال.

الثالث: أن تكون مرتبطة إما بالواو و الضمير أو بالضمير فقط أو بالواو فقط.

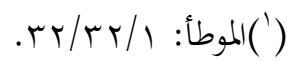

$$
\begin{aligned}
& \text { (") المشكلات، لابن السيد، ص ال7. }
\end{aligned}
$$

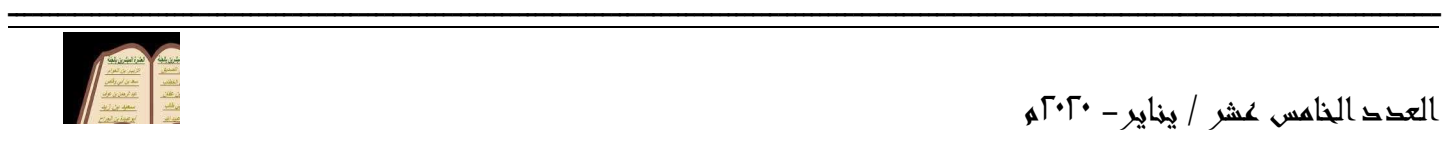


إذن فالجملـة الحاليـة لابــــ أن يكون لهـا رابط سـواء أكانت إسـية أو فعليـة، وسـواء أكـان فعلها ماضـي أو

مضـارع، ويجب في الماضي المثبت المتصرف غير التالي إلا والمتلو بــ(أو) أو العـاري من الضمير (قد) مع (الو او)، كقوله: (فجئت وقد نضت لنوم ثيابها)، فإن كان جامداً كـ(ليس) أو منفياً بـ(لا)، نحو: (جاء ز د ومـاطلعت الثمس) بالو او فقطو (جاء زيد وما دري كيف جاء) بالو او وا مير ، و(جاءز د ومادرى) بالضمير فقط، وكذا التالي إلا أو المتلو بـ(أو)، أما إذا كان الفعل ا اضـي مثبتاً، وفيه الضمير فقد ا تلف ـه النحاة ، فذهب الكوفيون ومعهم الأخفش من البصريين إلى القول بجواز وقوع الفعل الماضي حال سو اء أكان معه (قد) أو لم تكن معهه دون

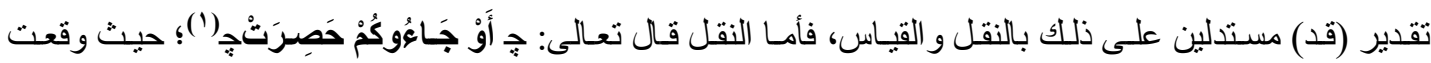
(حصرت) موضع الحال، ومما يدل على صحة ذللك قول أبي صخرة الهلالي:

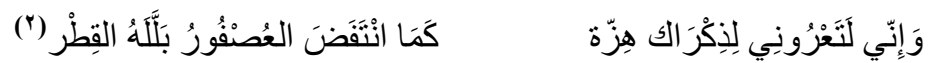

حيث وقع (بلله) و هو فعل ماضي موضع الحال، أما القياس فهو أن كل ما جاز أن يكون صفة نكرة نحو: (مررت برجل قاعد) جاز أن كون حالاً للمعرفة، مثل: (مررت بالرجل قاعداً)، فالفعل الماضي جوز أن يكون صفة للنكرة، نحو: (مررت برجل)، فقد يجوز أن يقع حالاً للمعرفة، نحو: (مررت بالرجل قعد)، وأيضـاً الإجماع

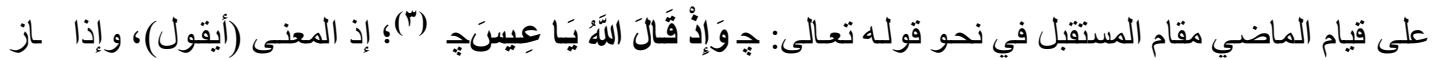

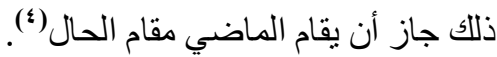
أما البصريون فلا يجيزون ذللك، فقد ردوا على ـاذ ب ب إليه الكوفيون حتى أن المبرد جعل مـا ذهبوا إليه ومعهم الأخفش قبيحاً؛ وذلك لأن الحال لما أتت فيه (الفعل) لما مضى فلا يقع في معنى الحال.

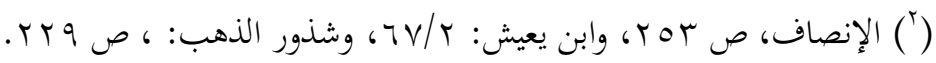

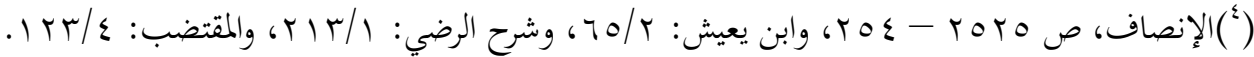


أما السيوطي في الهمع فيرى أنه إذا كان ا فعل الماضـي ثتباً، وفيه اضمير وجبت (قد) أيضـا لتقربه من

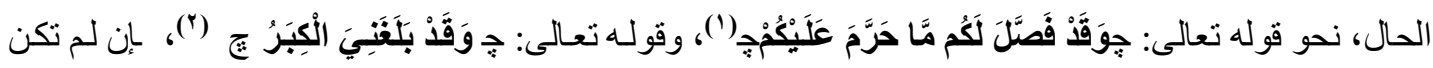

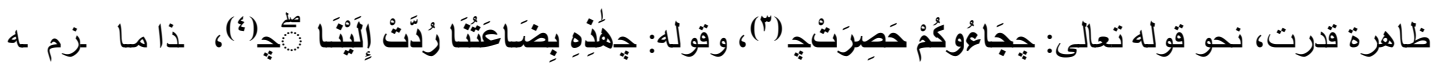
المتأخرون، كابن عصفور ، والأبذي، والجزولي، والمبرد، والفارسي (॰). قال الصبان: "مذهب البصريين إلا الأخفش لزوم (قد) مع الفعل الماضي المثبت مطلقاً أو مقدرة"(") أما المبرد فيرى امتناع وقو ع الفعل ا اضي حالاً مطلقاً لعدم دلاته على الحـال، و عدم صلاحيته قوع حالاً، أما احتجاج الكوفيين بالآية ورودها دليلاً على وقوع الفعل الماضي حالاً مدفوعاً بو احد من أربعة أوجه:

$$
\text { الأول: أن تكون (حصرت) صفة لـ(قوم) المجرور في الآية. }
$$

الثاني: أن تكون صفة لل(قوم)، فقد رأى (جاؤوكم قوماً حصرت صدور هم)، وهو جائز بالإجماع.

$$
\text { الثالث: أن يكون خبراً بعد خبر. }
$$

$$
\text { الر ابع: أن يكون محمو لاً على الدعاء لا على الحال(v). }
$$

$$
\text { و أما بيت الثعر فعلى تقدير (قد) التي حذفت للضرورة الثعرية. }
$$

ورد ابن الأنباري و ابن يعيش(') احتجاج الكوفيين وقوع الماضي حالاً للمعرفة على وقوع صفة للنكرة بـأن ذللك فاسد؛ لأن اسم الفعل الذي قاسوا عليه الماضي ير اد به الحال، أما الماضي فلم يجز أن يقع حالاً؛ لأنه لا ير اد بـه

$$
\begin{aligned}
& \text { (') (')سورة الأنعام، الآية } 11 \text { (1) }
\end{aligned}
$$

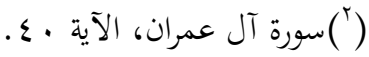

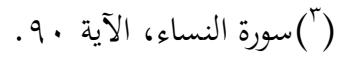

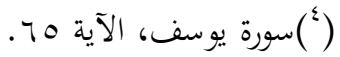

$$
\begin{aligned}
& \text { T }
\end{aligned}
$$

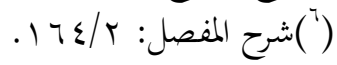

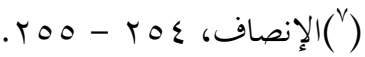

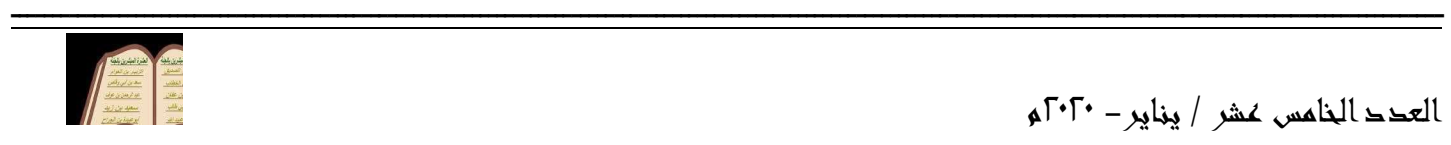


الحال(")، كما رد ابن الأعر ابي(") قو لهم قيام الماضي مقام المستقبل في بعض المو اضع، كما في قوله تعـالى: جِوَإِّْ

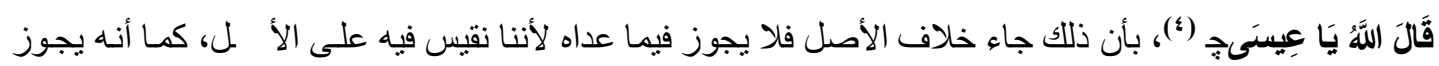
أن يقع الماضي في بعض المو اضع حالاً إذا دخلت عليه (قد) أو كان وصفاً.

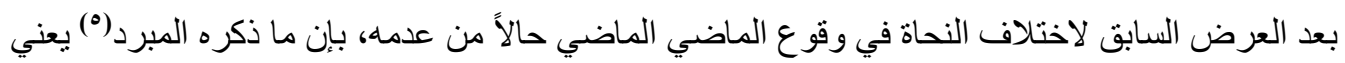
أنه برى امتناع وقوع الفعل الماضي حالاً مطلقاً في حين بمنع باقي البصريين وقوعه إذا لم بقترن بعد ظاهرة أو مقدرة، وأما الكوفيون ومعهم الأخفش من البصريين يجيزون وقوع الفعل الماضي حالاً دون تقدير (قد)، و أرى أن الأولى بالقبول في هذه المسألة هو رأي الكوفيين ومن وافقهم؛ لأنهم بنوا كلامهم على أساس متين من القياس و السماع و إن كان ابن البِّيّد قد اختار مذهب البصريين.

(') الإنصاف في مسائل الخلاف بين النحويين: البصريين والكوفيين: عبد الرحمن بن ثُحَّمَ بن عبيد الله الأنصاري، أبو

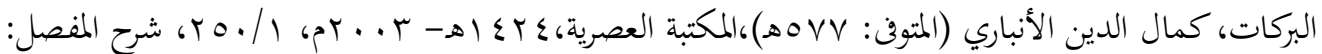

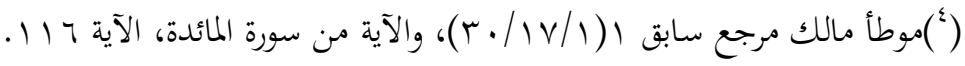

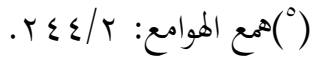




\section{ثانيا: مسائل في الفعل المضارع 1-جزم الفعل المضارع في جواب النهي:}

حدثني يحيِ عن مالك بن شهاب عن سعيد من المسيب أن رسول الله صلى الله و عليهاه وسلم قَال: (مَنْ أَكَلَ

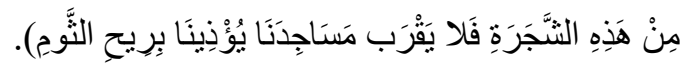
يرى ابن مالك(') أن رطحة الجزم ي و اب النهي هو أن تقع (لا) بعد إن الثرطية امقدرة بشرط صحة المعنى نحو: (لا تَنْنُ من الأسد تسلْم) فجاز و ع أن قبل (لا) النافيـة فيكون امعنى: (إن لا تدنُ من الأ دـ تسلم )؛ لأن اسـلامة سبب دم ا نو فصح الجزموو ب ارفع في نحو (لا تدنُ من الأ دـ أكلك) لأن الأكل لا يتسبب إلى عدم الدنو و إنما يتسبب عن الدنو نفسه، و إلى هذا أثشار ابن ماللك بقوله:

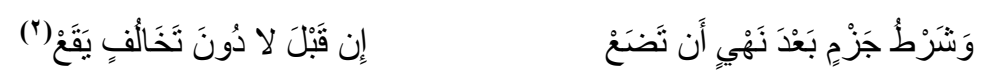

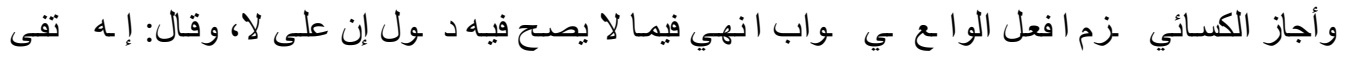

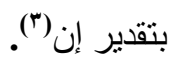

وقال خالد الأز ري: إله نسب عدم اثشتر اطصحة و وع (إن) قبل (لا) الناهية إلى الكوفيين افة، و إنهم احتجو ا على صحة رأيهم بالقياس على النصب كما هو جائز النصب في قولنا (لا تدنُ من الأ د أكلك) وفي قوله.

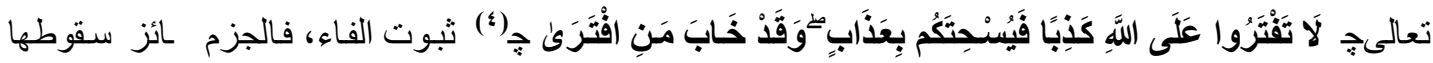

$$
\begin{aligned}
& \text { (') شرح الكافية: // 10016 100 1. }
\end{aligned}
$$

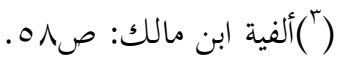

$$
\begin{aligned}
& \text { (ع)شرح الكافية: س/ 100 10 } \\
& \text { (") سورة طه، الآية: ال7. }
\end{aligned}
$$

$$
\text { العقد الخاهس عشر / يناير - •Г·م }
$$




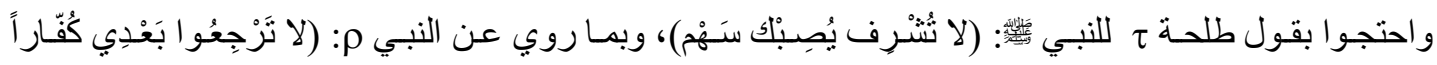

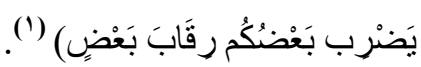

ورد ابن عصفور على استدلال الكوفيين بقول طلحة إن هذا يعد من تسكين المرفوع والذي لا يجوز إلا في

$$
\text { الضرورة أو في قليل من الكلام. }
$$

$$
\text { فَالِيومَ أَنْرَرَبْ غَيرَ مُسْتحقب }
$$

حيث جاء الفعل المضار ع أنشرب مجزوم رغم إنه لا يسبق بجازم وذللك للضرورة الثعرية.

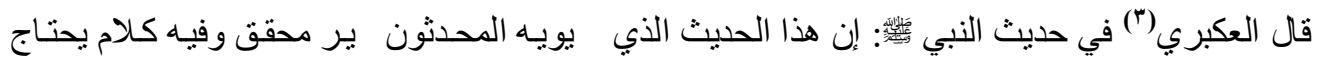

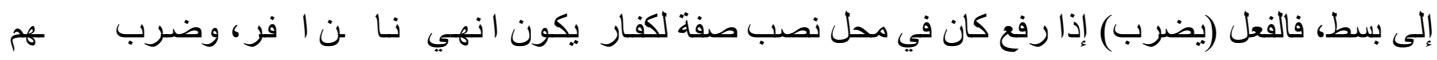
رقاب بعض فأيهما فعلوا فقد وجد المنهي عنه إلا أنهما إذا اجتمعا كان النهي أشند.

وقال بعض العلماء: إن النهي في الحديث عن الصفة الثانية ألا وهي رب بعضهم ر ماب بعض، و لـله قول الرجل لزوجته: أنت طالق إن كلمت رجلاً طويلاً، فإن كلمت رجلاً قصيراً فلن تطلق، فكذلك إذا رجعو ا كفاراً،

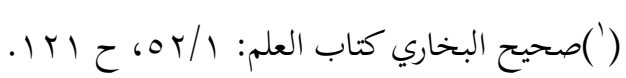

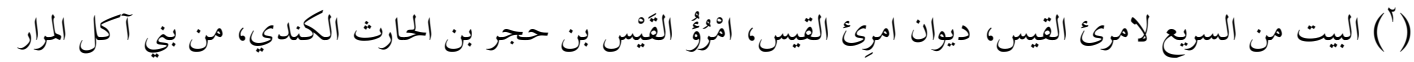

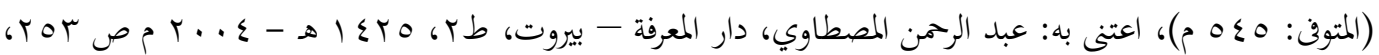
والرواية فيه أسقي. (") إعراب ما يشكل من ألفاظ الحديث النبوي: أبو البقاء عبد الله بن الحسين بن عبد الله العكبري البغدادي محب الدين

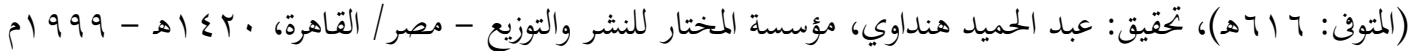


ولم يضرب بعضهم ر ماب بعض وهذا القول فيه بعد؛ لأن ا فر قد علم انهي نهـ من دون أن يضرب بعضهم

$$
\text { رقاب بعض. }
$$

ويجوز أن يروى يضرب بالجزم على لير شرط ضمر؛ أي إن جعوا كفاراً يضرب ضكم رقاب

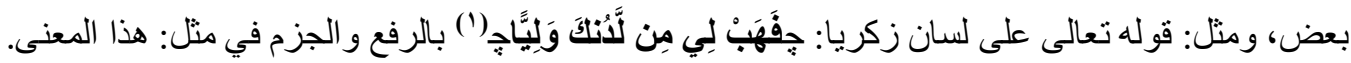
ولكن أكثر المحققين من النحويين لا يجيزون الجزم في مثل: هذا الحديث؛ لأن الجزم فيه ـ ا عنى فلو

قال: (لا ترجعو ا بعدي كفار اً تسلمو اوتو ادوا) كان المعنى مستقيماً؛ لأن التقدير: إلا ترجعو ا كفار اً نسلموا، ومتلكه في لي ذلك: (لا تدن من الأسد تنج)؛ أي: (إن لا تدنُ من الأ د تنجُ)، ولكن إن قلت: (لا تدن ن الأ ــ أكلك) و غير صحيح وفاسد.

$$
\text { (') سورة مريم، من الآية: ج · 1. }
$$


r - ت توكيد الفعل المضارع بالنون بعد لام القسم:

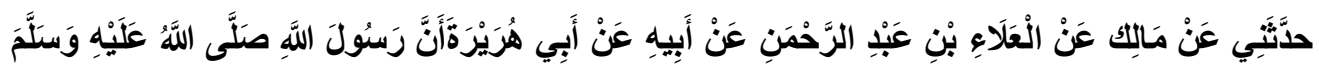

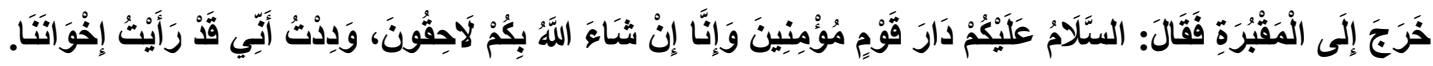

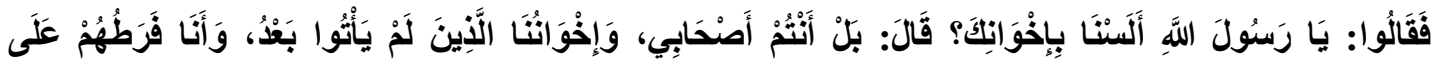

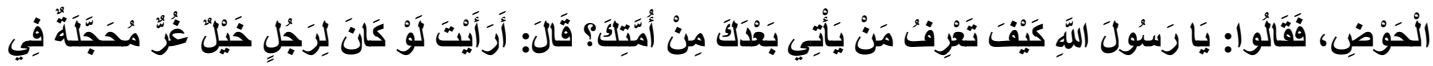

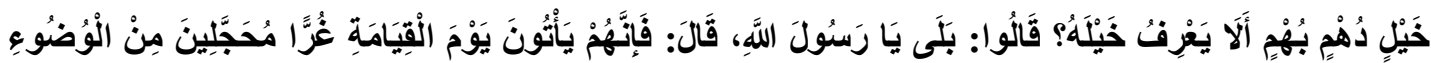

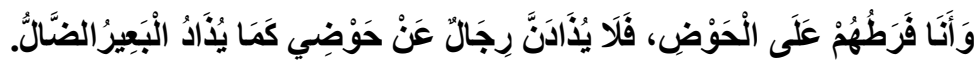
إن التوكيد من الأساليب العربية التي يلجأ إليها المتكلم لإثبات حالة ما أو تقرير ها في ذهن المخاطب فنون التوكيد من لو ازم الأفعال و التوكيد بها نمط خاص باللغة العربية لم تعرفه أي لغة أخرى من اللغات للسامية(')، فهي تدخل على المضار ع و الأمر دون الماضي لأنـه يدل على الزمن الماضـي و النون تخلص الفعل للمستقبل (†) سو اء أكانت نون للتوكيد ثقبلة أو خفيفة. وللفعل المضار ع مع التوكيد بالنون أحكام ثلاثة، وهي: وجوب التوكيد شريطة أن يكون الفعل مثبتاً، وأن

$$
\text { يكون جو اباً للقســــ و أن يتصـل بـ(لام القسم) اتصـالاً مباثـــراً }
$$

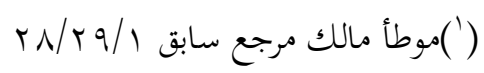

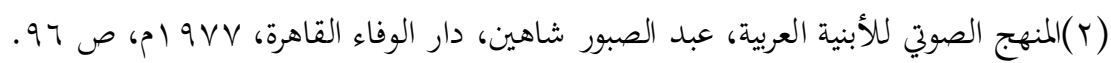

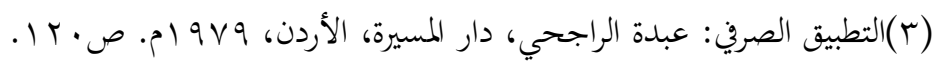

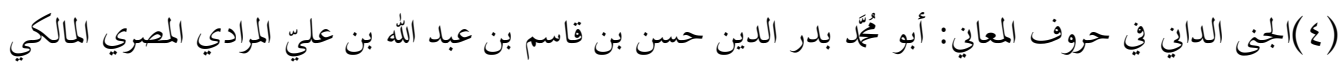

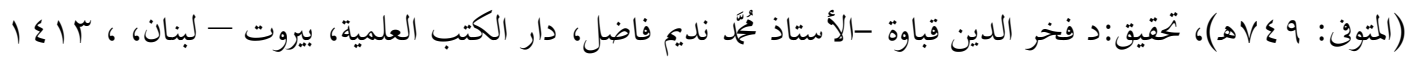

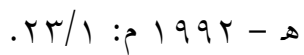

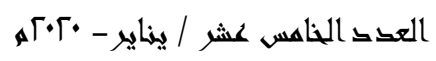




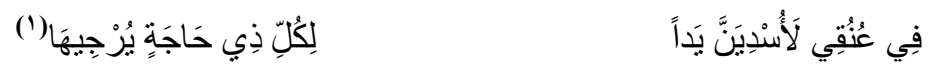

فالفعل: أسدي جو اباً للقسم متصل باللا مثبتاً دال على الاستقبال.

أمـا جو از التوكيد، فيؤكد الفعل المضـارع بـالنون في مو اضـع منها وقوعهـا شرطاً؛ لأن المؤكدة بـ (مـا)

الزائدة، وإذا دل على ا طلب كأن تصل بلام الأ ر أو النهي أو الدعاء أو و ع بعد رض أو مني أو رجي أو ر

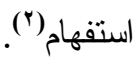

و واختلف في جو از توكيده أو وجوبه بعد إما، فقد ذهب المبرد والزجاج إلى أن توكيده بعد (إما) واجب("). أما دخول نون التوكيد في مستقبل فيه معنى الطلب فهو الأغلب المشهور، قال الرضي: (وأ ـا ي المستقبل

الذي هو خبر محض فلا تدخل إلا بعد أن يدخل على الفعل ما يدل على التأكيد كلام القسم نحو: (و الله لأضرِبَنَّ) و L المزيدة نحو إما: (إما تفعلن لَيَكُون ذاك)، الأول توطئة للدخول ون النوكيد و إيذاناً بها(؛)، لمسا دل ليه النون من استقبال دون أن يكون ذلك من الوجوب ( فإن شئت أقحت النون و إن شئت ركته كما فعل ذلك ـي الأ ر و النهي نحو قوللك (هل تقولن؟ أو تقول ذلك).

$$
\begin{aligned}
& \text { (') المقتضب: ك/r ع ـ . } \\
& \text { (") التراكيب اللغوية، ص: بس ا. }
\end{aligned}
$$

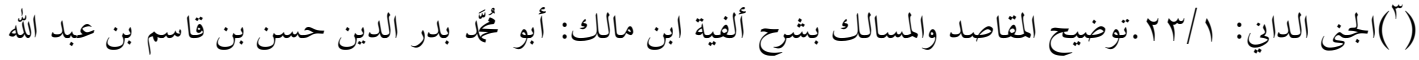

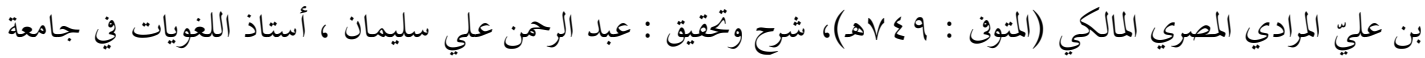

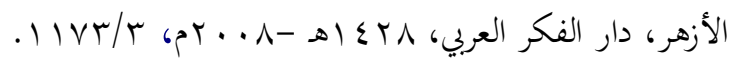

(") شرح الرضي على الكافية:رضي الدين الأستراباذي، تصحيح وتعليق: يوسف حسن عمر الاستاذ بكلية اللغة العربية

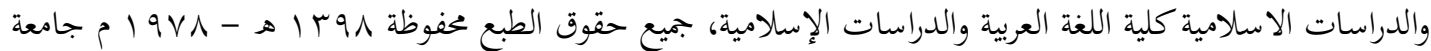


أما الثالث فهو امتناع التوكيد إذا لم يكن هناكَ ما يوجب توكيده فلا يؤكد نحو قوله تعالى: جِوَلَسَوْفَ يُمْطِيََّ

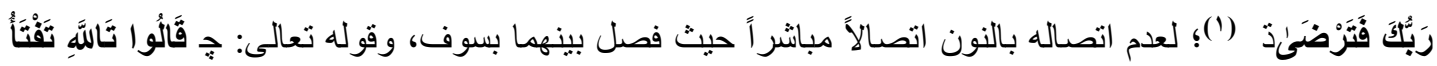
تَنْكُرُ يُوسئفَ ج)(") لكون الفعل منفباً ولا تختلف نون التوكيد الخفيفة عن الثقبلة في تأكيد الفعل المضارع سوى في بعض الأحوال الإسنادية، فتنفرد النون الثقيلة بوقو عها بعد ألف الاثثين، والألف الفاصلة إثري نون الإناث و لا تقع الخفيفة بعد الألف عند البصريين، وأجاز يونس والكوفيين(") وقو عها بعد الألف، بمعنى أن النون الخفيفة لا تأتي مؤكدة في موضعين: بعد الفعل المسند إلى ألف الاثثين، و إلى نون الإناث، و هذه المسألة فيها خلاف بين الكوفيين والبصريين، فأجاز الكوفيون دخول نون التوكيد الخفيفة على فعل الاثنين وجماعة الإناث نحو: أفَفعلان وأَفْعَنًْا واحتجوا على رأيهم بوجهين، أحدهما إن هذه النون الخفيفة مخفقة من الثقيلة، و إن النون الثقيلة تدخل في هذين الموضعين وكذلك النون الخفيفة، و الثاني: هذه النون إنما دخلت في القسم والأمر و النهي والاستفهام والثرط بإما لتوكيد الفعل المستقبل، فكما يجوز إذخال لتوكيد على فعل مستقبل وقع في هذه المو اضع(؛). وذهب البصريون بأنه لا يجوز إدخال نون التوكيد في هذين الموضعين واتجوا بإنه لا يجوز دخول نون التوكيد الخففة في هذين الموضعين؛ لأن نون الاثنين التي للإعراب تسقط، فنون النوكيد إذا دخلت على الفعل المعرب أكدت فيه الفعلية فردته إلى أصله وهو البناء، فإذا سقطت النون بقيت الألف فلو أدخل عليها نون التوكيد الخفيفة فلم يخل إما أن تحذف الألف أو تكسر النون أو تقر ساكنة، فلا تحذف النون لأنه بحذف يلتبس فعل الاثثين

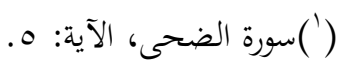

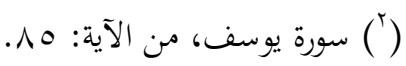

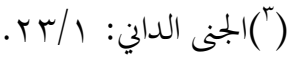

$$
\begin{aligned}
& \text { (") الإنصاف في مسائل الخلاف بين النحويين: البصريين والكوفيين: عبد الرحمن بن يُحّمّ بن عبيد الله الأنصاري، أبو }
\end{aligned}
$$

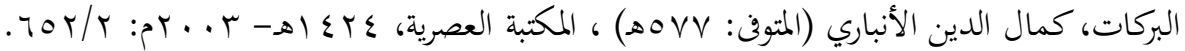


بالو احد وبطل أن تكسر النون لأنه لا يعلم هل هي نون التوكيد أو نون الإعراب وبطل أن تقر ساكنة لأنه يؤدي إلى أن يجمع بين ساكنين مظهرين في الإدر اج.

\section{rـ نصب الفعل المضارع بعد فاء السببية الواقعة في جواب النفي:}

ينصب الفعل المضارع بعد فاء السببية ريطة أن سبق بنفي محض أو طلب محض(")، فلالنفي المحض يأتي على عدة صور، و لا فرق بين أن يكون باسم أو بفعل أو بحرف، فالنفي باسم، نحو: (جارك غير مقصر

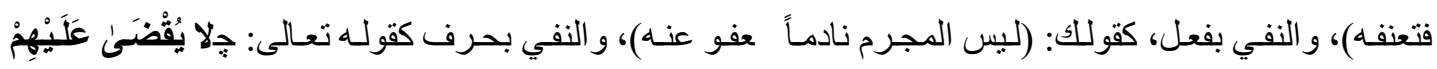

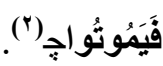

و إذا كان النفي غير محض فإن ا فعل لا نصب لل يجب رفعه، و النفي اذي ليس بمحض وهو ا نتنض بـ(إلا) و المتلو بنفي، مثل: (ما أنت تأتينا إلا وتحدثنا)، ونحو: (ما أنت تأتينا إلا فتحدثنا)، وكذلك النفي التالي تقريراً، نحو: (ألم تأتينا فأحسن إليك) إذا لم ترد الاستفهام الحقيقي("). و على ذللك ترى الباحثة أن المدار في الحكم على المعنى، فإلا تنقض النفي في ون حم الإثبات، و النفي في نحو (ما تز ال) لفظي ومعناه الإثبات كقوللك: (لا يز ال أخوك ييرنا فنحبه)، فالمعنى (أخوك مستمر على برنا). أما الطلب المحض فالمقصود به ألا يكون الطلب باسم الفعل، مثل: (صـه فينام النـاس)، أو لمصدر، مثل: (ضرباً زيداً فيتأدب)، وبالخبر : (حسبك يستريح الناس)، أو يكون الأمر مقدراً، نحو: (الأسد الأسدفتنو)(؛)، فلا

(') اللمع في العربية: أبو الفتح عثمان بن جني الموصلي (المتوفى: بو بهـ)، تحقيق: فائز فارس، دار الكتب الثقافية -

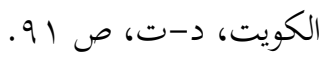

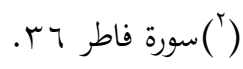

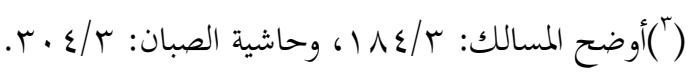

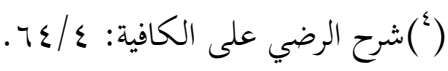


يكون مـن ذللك جواب منصـوب، ويتضـمن الطلب ثمانيـة أثنياء، وهي: (الأمـر ، و النهي، و الدعاء، و الاسـتفهام،

$$
\text { و التمني، و الترجي، و العرض، و التحضيض). }
$$

فالأمر يقصد به الأمر بفعل الأ ر و المضـارع المقرون بـلام الأمر، و و طلب الفعل على وجه الاستعلاء

$$
\text { فهو أعلى منزلة من خاطبه أو يوجه إليه الأهر (')، و الطلب بالأمر مثل: (كن سخي الكف فتسود). }
$$

و النهي، ويعد طلباً فهو طلب ترك الفعل و الكف عنه على وجه الاستعلاء والإز زام مثل: ولـه تعالى: جِوَلَا

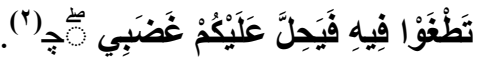

أما الدعاء، وهو طلب على سبيل التضر ع ويكون اخطاب فيهـ ن الأدنى إلى ـن هو أعلى زلـة دعاء

$$
\text { الإنسان ربه، وهو داخل في باب الأمر و النهي عند النحاة("). }
$$

الاستفهام، وهو طلب العلم بشيء لم يكن معلوماً من قبل بأداة مخصوصة(") سو اء كان بحرف مثل: (أ أتيني

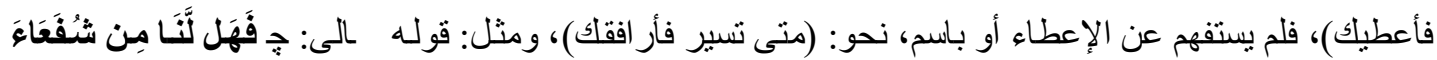

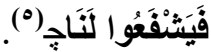

التمني، وهو طلب أمر محبوب لا يرجى حصوله إما لكونه مستحيلاً وإما لكونه ممكناً غير مطموع في

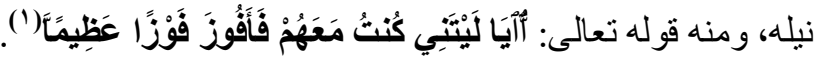

(') علم المعاني: عبد العزيز عتيق (المتوفن: جو ب 1 هـ)، دار النهضة العربية للطباعة والنشر والتوزيع، بيروت - لبنان،

.VTrp r...q- ه $1 \leqslant r$.

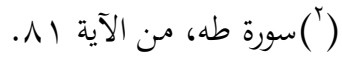

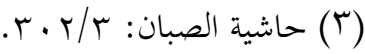

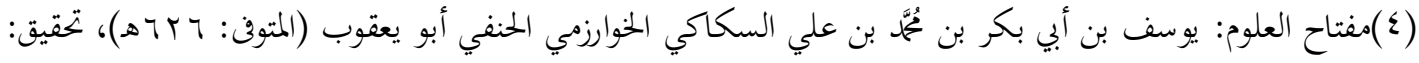

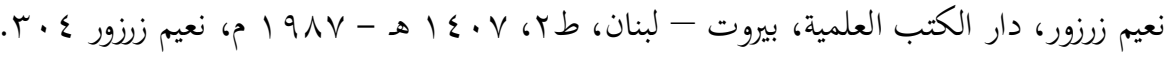

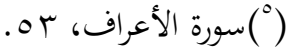

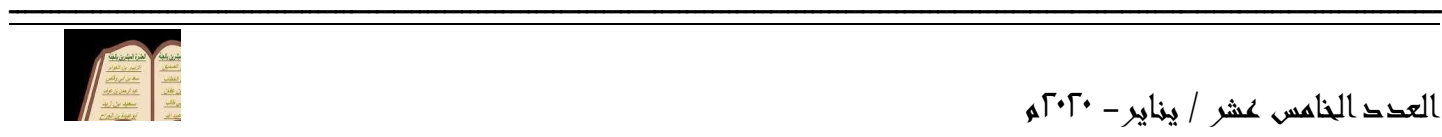




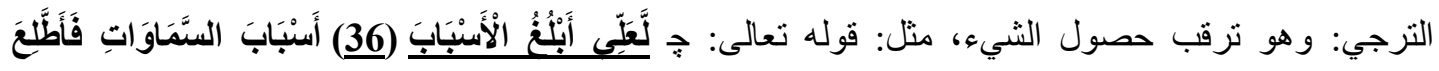

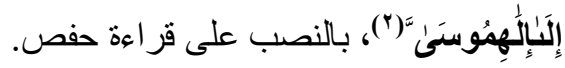
أما العرض فمثل: قولك: (ألا تزورنا فنعطيك).

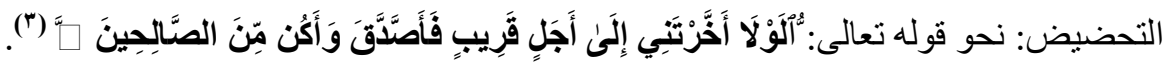
و هذه الثمانية هي ما يسميها النحويون الجواب بالفاء وسمي جو اباً؛ لأن الأول سبب اثناني، ألا رـى أنك إذا

$$
\text { قولت (زرني فأزورك) كان المعنى إن تزورني أزرك(4). }
$$

و إن كل موضع تجيء فيه فاء السببية في جواب الطلب يكون الفعل المضار ع منصوباً، فإذا سقطت الفاء في جو اب

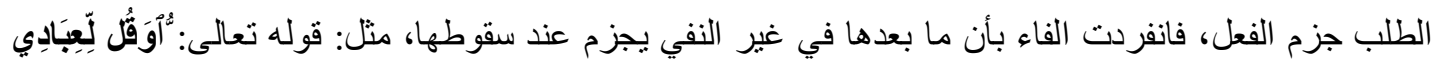

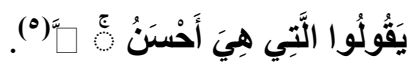
وحاصل ما تقدم أن هذه الأجوبة الثمانية كل شيء منها جو ابه بالفاء منصوباً، وكان بغير الفاء مجزوماً، إذا يبطل الجزم مع النصب بالفاء، ويجوز الرفع فالجواب الجز اء بالفاء مرفوع.

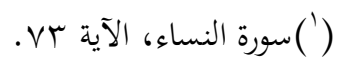

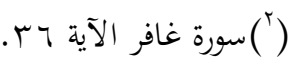

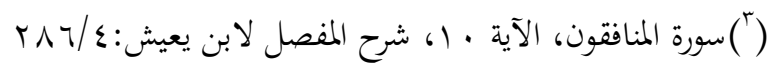

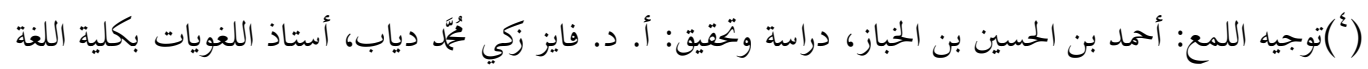

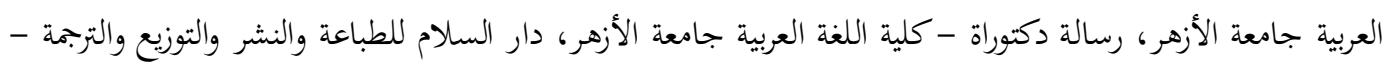

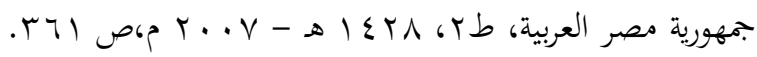
(") سورة الإسراء، الآية به، فتح رب البرية في شرح نظم الآجرومية (نظم الآجرومية لمحمد بن أبَّ القلاوي

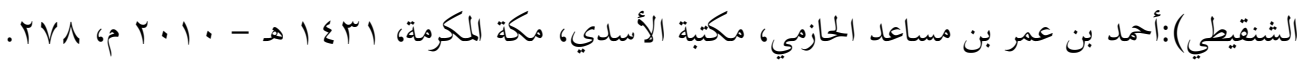


ع ـآراء النحاة في ناصب المضارع بعد فاء السببية:

ذهب معظم النحويين، ومنهم المبرد وا ن هشـام(1) إلى أن الفاء رف مهمل خلافاً بعض الكوفيين ا ذين يرون أن الفاء صبة، مثل: قولك: (مـا تأتينا فتحدثنا)، وإن الأ ل يها أن ترد عاطفة، ثل: قولك (أ أزورك

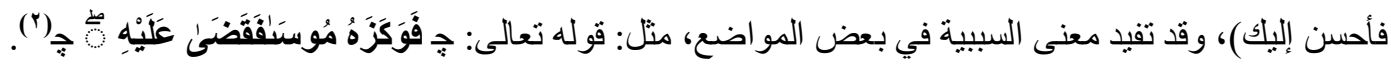
فالنحاة في ناصب الفعل المضار ع المقترن بالفاء خلافاً على ثلاثة أقو ال(")، هي:

الأول: يرى البصريون أن الفعل المضارع نصوب بأن ضمرة وجوباً بعد الفاء، و الفاء عاطة مصدراً مقدراً على مصدر متوهم، فإذا قلت: (أ رمني فأحسن إليك) و التقدير : ليكن ن إ رام فإحسـان مني، و جتهم في ذللك أن الفاء لا تنفك عن معنى العطف و الربط، وهي لا تختص بالفعل بل تنخل على الاسم و الفعل و الحرف؛ ولذلك تحتاج إلى إضمار لاستحالة العطف هنا على اللفظ(؛). الثاني: يرى الكوفيون أن ناصب الفعل المضار ع هو الخلاف بين ما تقدم على الفاء وما تأخر عنها؛ لأنه لما لم يصح عطفه على الأول لمخالفته له في المعنى نصب، و هذا ما أنثار إليه ا مبرد قوله: "و إنمـا يكون إضمار أن مخالفة الأول ا اني لو قلت: (لا تقم فتضرب زيداً) لجزمت إذا أردت لا تقم ولا تضربز داً، فإذا أردت لا تقم فتضرب زيداً؛ أي: فإنك إن قمت ضربته لم يكن إلا ا نصب؛ لأ لك لم قصد يضرب انهي فصسار ا معنى: لا يكن

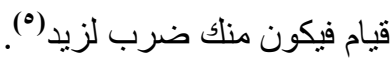

$$
\begin{aligned}
& \text { (')(المتتضب: r/ 1/، ومغني اللبيب: 1/7/7 ا. } \\
& \text { (") سورة القصص، الآية } 10 \\
& \text { ( ) (الإنصاف: (r) }
\end{aligned}
$$

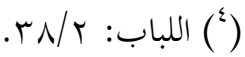

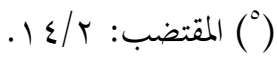

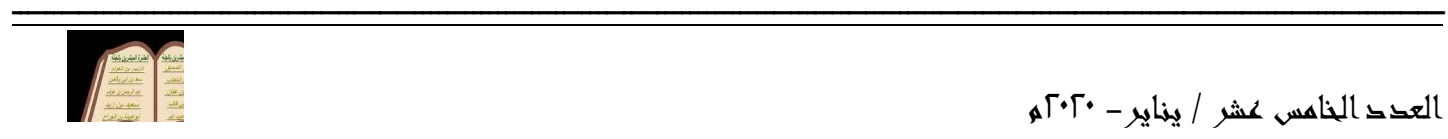


فالمضار ع المنصوب بأن مضمرة بعد فاء السببية مؤول بمصدر معطوف لـى مصدر منتزع من ا فعل

ويرى الكسائي وأبو عمرو الجزمي(') من الكوفيين أن الفاء هي الناصبة للفعل بنفسها.

ولذا فإنني أميل إلى رأي البصريين و أضعف قول الجزمي، وأبطل ما ذ ب إ ـهـ الكوفيون؛ لأن الأصل في حرف الفاء أن يكون للعطف و الربط بين الأسماء والأفعال فهو حرف مشترك و لا اختصاص له. أما الرد على قول الكوفيين فيقول ابن الأنباري: "لو كانت الفاء هي الناصبة بنفسها لخرجت عن ها؛ و ذا يجوز دخول حرف العطف يها، مثل: إيتني و أكرمكوفأعطيك، وفي د بول رف العطف يها دليل على أن

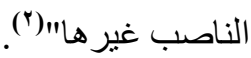

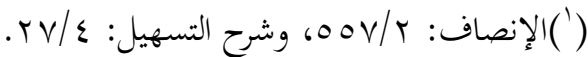

$$
\begin{aligned}
& \text { ( ) (الإنصاف: (r) }
\end{aligned}
$$




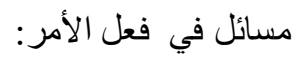

1- حذف لام الأمر في التراث النحوي:

معنى لام الأمر: هي لام وضعت ليتوصل بها إى الأمر من افعل، و ـهـ ـروف الزيادة، فلام الأمـر إذا بدأت بها الكلام اءت مكسورة، و إن اقترنت رف من حروف العطف (الواو - الفاء - ثم) جاز فيها الكسر

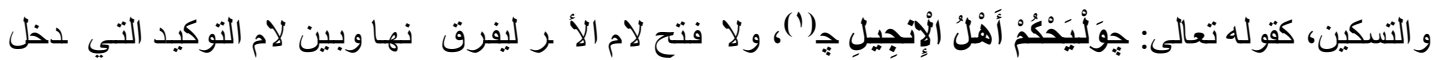

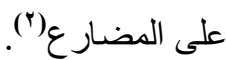
ولام الأمر هي الموضو عة للطلب(")، وهي لام جازمـة للفعل المستقبل للمـأمور الغائب، وهذا هو أصل

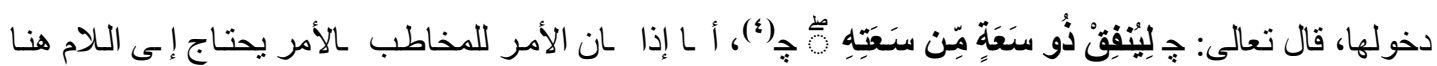
و إنما يستغنى عنها بصيغة (افْعَلْ)، مثل: قولك: اذهب، و انطلقى.

ويقول الزجاجي: إن لام الأمر ربما تدخل على المخاطب للتوكيد تقول: (لتذهب يازيد)، ركب وعلى ذا

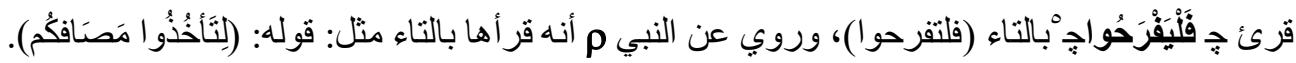

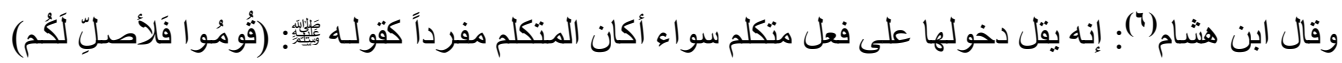

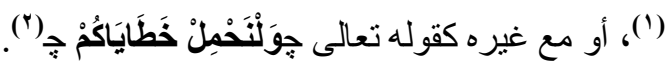

$$
\begin{aligned}
& \text { (') سورة المائدة، من الآية V\&، تاج العروس: }
\end{aligned}
$$

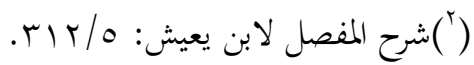

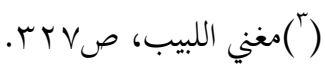

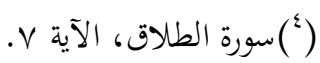

$$
\begin{aligned}
& \text { (0) يونس: مه }
\end{aligned}
$$

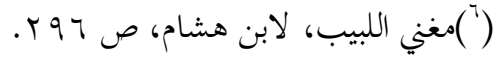




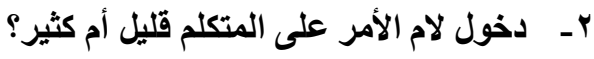

أقول إن دخول لام الأمر على المتكلم قليل جداً؛ لأن المتكلم لا يأمر نفسه إلا إذا أنزلها منزلة الأ نبي وهو في غنى عن ذللك لكنه فصيح جائز رغم قلته، كما ـال المالقي دليل وروده في يثه للنبي م في سنن اترمذي:

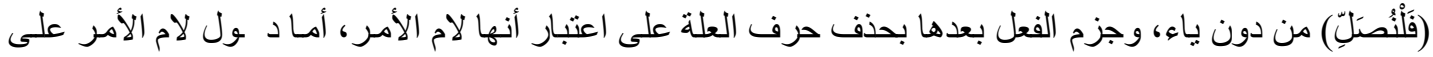
المخاطب فهو جائز رغم قلته، لكن الأجود منه عدم دخولها عليه والا تنغناء عنها بفعل الأمر اشرة، و ذذه لغة

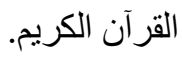

عمل لام الأمر: تختص لام الأمر بالدخول على الفعل المضارع الغائب، وقد تدخل على المتكلم و المخاطب، وهي لام جازمة للفعل المضار ع، وتثقى جازمة له و إن خرجت عن الطلب إلى غيره من الأغر اض(")، قـال تعالى:

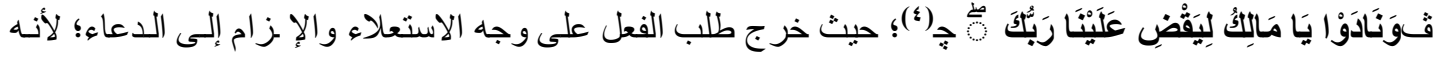
صدر من الأدنى منزلة إلى الأعلى منزلة، ورغم نلك اء ا فعل مجزوماً بلام الأمـر و علامـة جزمهـ حذف حرف

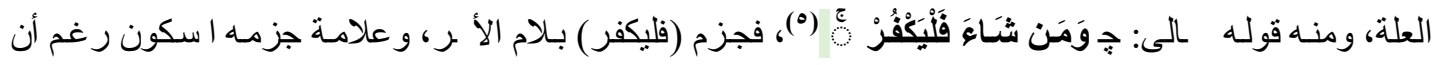
الكلام في الآية جاء على لفظ الأمر للتهديد.

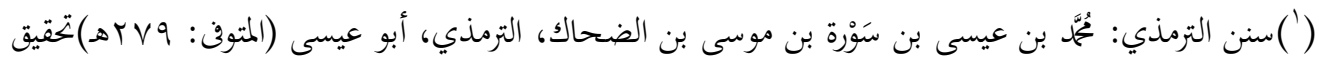

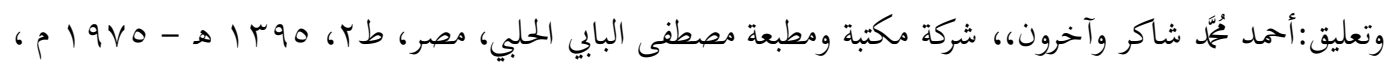

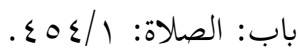

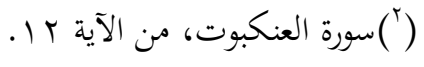$$
\text { ( ) مغني اللبيب، ص } 90 \text { r }
$$$$
\text { (") سورة الحجرات، من الآية VV. }
$$$$
\text { (") سورة الكهف، من الآية: وج؟. }
$$ 
وسبب الجزم بلام الأمر كما يقول ا كبري يعود إلى ون الأمر طلباً وهو رض ن أغراضه فأنشبهت

لامه لام المفعول له، وهي جارة فيجب أن تكون لام الأمر جازمة، فالجزم في الأفعال مقابل الجر في الأسماء('). ويرى ابن الور اق: أن السبب في جزم لام الأمر هو اثتتراك الأمر باللام و غير ها في ا معنى وخصت اللام بذلك؛ للذولها على الغائب فتشابهت في ذلك لام التعريف؛ لأنه لا تستعمل للعهد ولمن و ئب فأدخلت اللام من بين سائر الحروف لهذا المعنى (ץ).

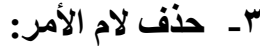

قال سيبويه("): و اعلم أن هذه يقصد لام الأمر قد يجوز حذفها في الثُعر وتعمل مضمرة، مثل: قول الثشاعر :

$$
\text { مُحَمَّد تَفْدِ نَفْسَكَ كُلُْ نَفْسِ }
$$

حيث حذفت لام الأمر من (تفذ) فالثاعر أر اد لتفد وعلى الرغم ن ذ لك بقي عملها فالفعل مجزوم و علامة

جزمه حذف حرف العلة.

وقد اختلف النحاة في حذف لام الأمر وبقاء عملها على أربعة أقو ال(ه):

الأول: جواز حذف لام الأمر في الاختيار مطلقًا بشرط أن تسبق بقول، وهذا هو مذهب ا سائي فـال تعالى:

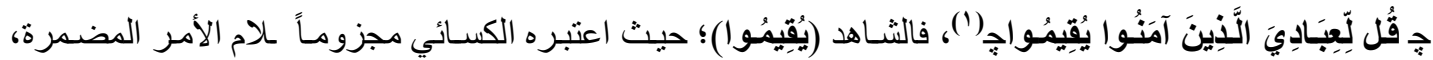

(')اللباب 》اشرح فصول الآداب):أبو مُحَّم عبد الله بن مانع بن غلاب الغبيوي الروقي العتبي، دار التدمرية، الرياض -

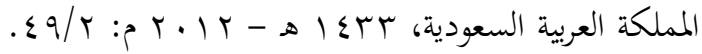

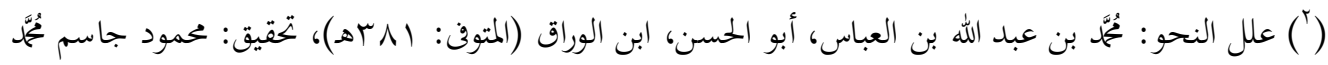

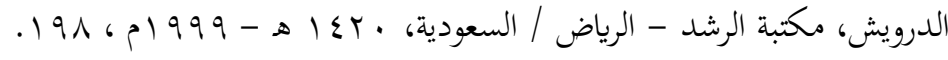

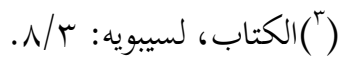

(")البيت من الوافر ومختلف فيمن قاله، قيل: حسان، وقيل: الأعشى، الكتاب: ب/N.

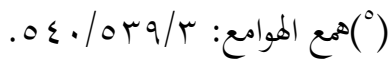

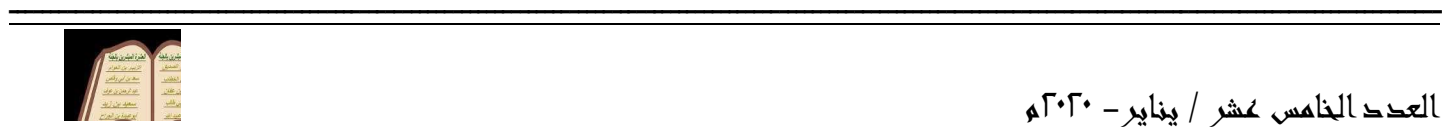


و التقدير: (عنده ليقيموا) فاللام محذوفة؛ لأنها جاءت بعد قول وبقي عملهار رغم حذفها فالفعل مجزوم و علامـة جزمهـ حذف النون لأنه من الأفعال الخمسة.

$$
\text { الثاني: وهو مذهب المبرد؛ حيث يرفض حذف لام الأمر ولو في الثعر. }
$$

الثالث: فيجيز حذف لام الأمر في ضرورة الثعر وعدم جواز حذفه في الا يار سواء بقه أ بر لقول أو لم بسبقه، واعتبر أصحاب هذا الدذهب أن سبب الجزم في الآية السابقة وهو وقوع الفعل جو اباً للطلب. الرابع: فيجيز أصحابه حذفها في الاختيار بعد قول ولو كان غير أمر، نحو: (قلت زيد يضرب عمراً)؛ أي ليضرب، و لا يجوز غيره إلا في ضرورة، وهذا مذهب ابن مالك،، والذي جعل حذف لام الأمر ي الاختيار دون أن يسبق بقول أمر أقل من حذفه بعد قول أمر، و استدل على ذلك بقول الثـاعر:

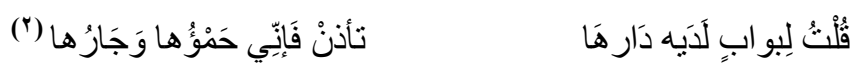

حيث حذف لام الأمر ن (تأذن) وا تبر ا ن الك أن الحذف هناليس ضرورة لتمكن ا ـاعر من قول

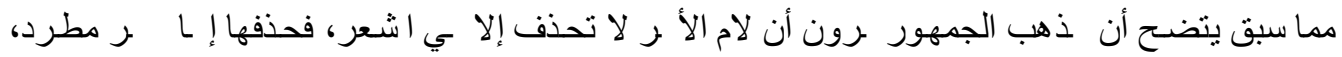
وذلك بعد الأمر بالقول ـ كما ذكرت - و إما قليل جائز في الاختبار، وإما قليل مخصوص بضرورة الثثعر.

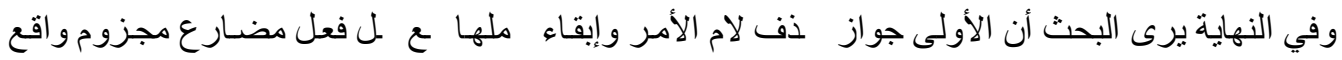
بعد القول بالطلب، و هذا ا ذهب إليه الكسائي و الزجاج زابن مالك و الأشموني؛ وروود اسماع هه، و اء ي القرآن

(') البيت من الرجز، لمنصور بن مرثد الأسدي، شرح الكافية: لابن جماعة، تحقيق: ثُمَّمَ عبد النبي عبد المجيد، طا، $.10 \mathrm{~V} \cdot / \mathrm{r} \operatorname{col} 9 \mathrm{NV}$ 


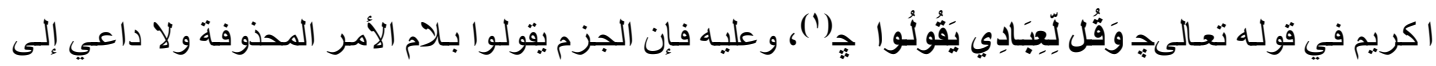
التكلف لتخريج الجزم في الآية.

ـ- - كيف يكون الأمر للمتكلم و المخاطب و الغائب؟

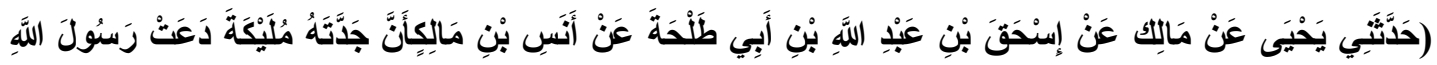

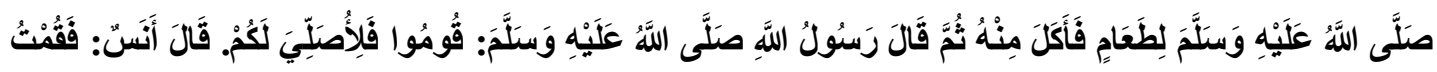

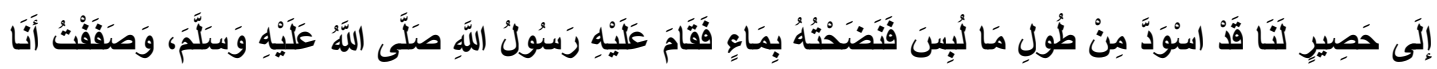

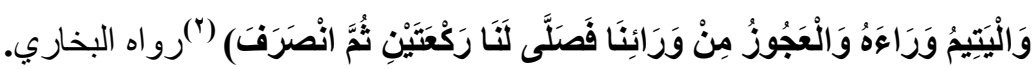
ذهب معظم النحاة إلى أن لام الأمر جازمة للفعل المستقبل المأمور الغائب، وهذا هو أصل دخولها عنده فقد تدخل على المخاطب توكيداً، كمازعم الزجاجي؛ حيث يقول: "لام الأمر جازمـة للفعل المستقبل امـأمور الغائب،

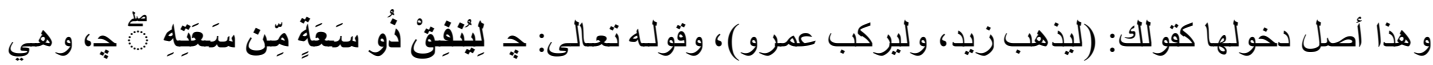
كثثرة الورود في كتاب الله والثعر والنثر، فإذا أمرت مخاطباً فأنت غير محتاج إلى اللام، كقولك: (اذهب يـازيد و انطلق يا عمرو) فأدخلت اللام على الفعل للتوكيد، و على هذا هذا قرئ (وبذللك فلتفرحوا) لتاء، وقرأ أكثر القراء

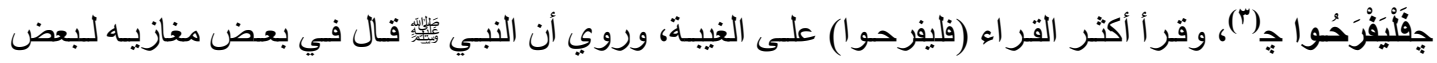

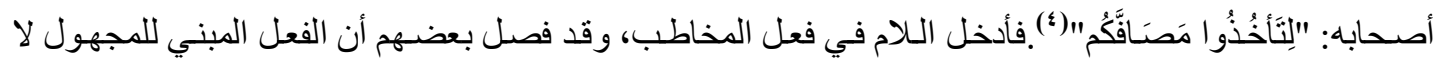

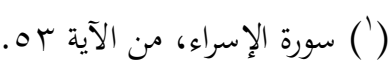

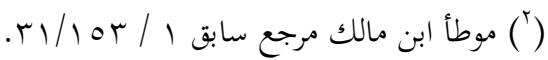

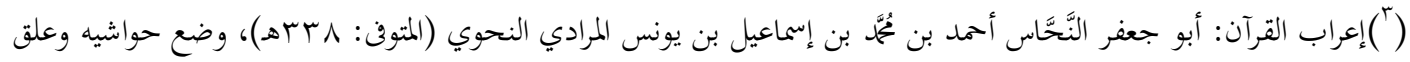

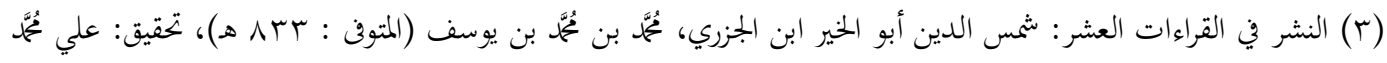

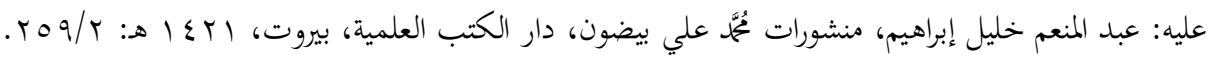

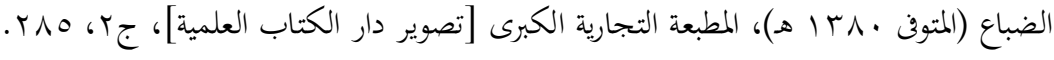


يكون الأمر فيه إلا باللام سواء أكان للمتكلم، نحو: (لأعن بحاجتي)، أم للمخاطب، نحو: (لتعن بحاجتي)، أم للغائب،

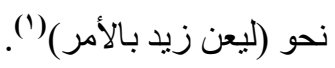

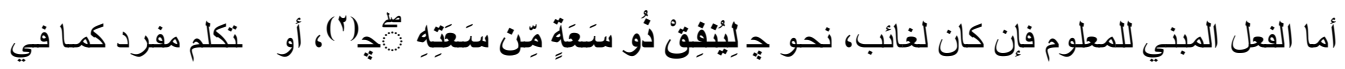

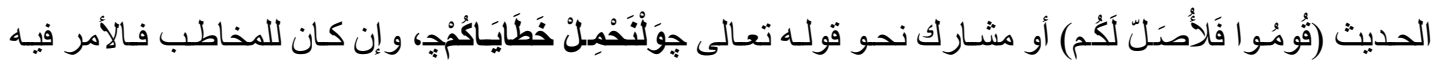

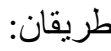
الأول: بصيغة أفعل، وهو الكثير، مثل: أعلم، والثانية باللام وهو قليل، قال عضهه: وهي لغنة رديئة، وقـال

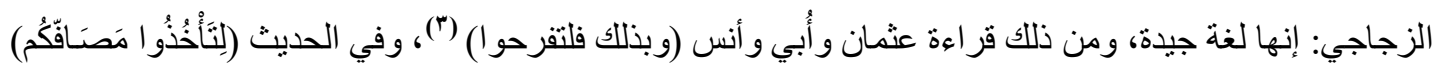
() ، ويفهم من كلامهم إلك إذا أمرت المخاطب بالفعل ا بني للمعلوم إن الأكثر فيه أن يكون بغير لام أي فعل

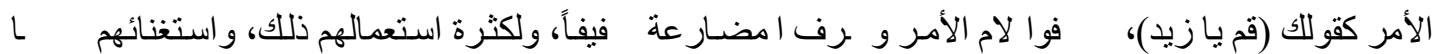
بخطابه ومو اجهته، ويجوز أن تأتي باللام في المخاطبة على الأصل، فتقول: (لتقم يازيد)، وروي عن زيد بن ثابت (فبذللك فلتقرحو ))، وقرئ قر اءة زيد بن ثابت (فبذلك فليفرحوا) و هو البناء الذب جعل للأمر فإن العرب تحذف اللام

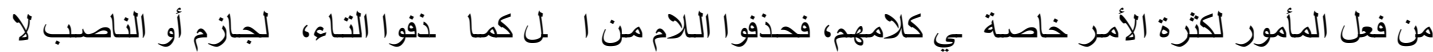
يقعان إلا على الفعل المضارع، فلما حذفت التاء ذهبت باللام وأحدثت الألف في قوللك: ا ـرب و ا رـح؛ لأن الضـاد

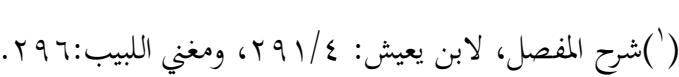

$$
\begin{aligned}
& \text { (") سورة الطلاق، من الآية V. }
\end{aligned}
$$

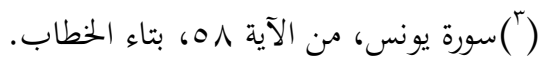

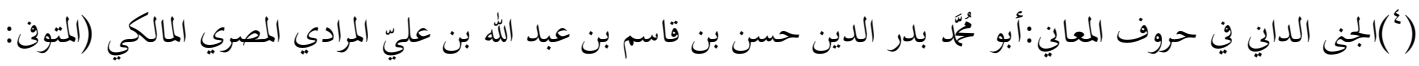

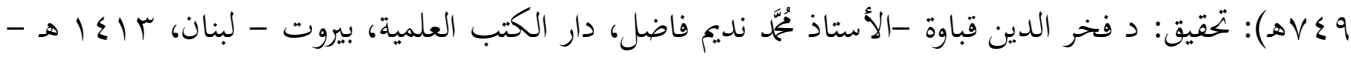




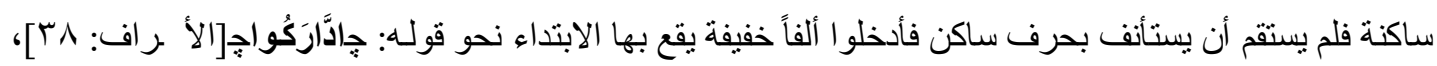

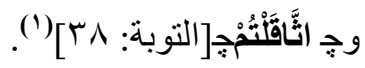
إذن الغالب في لام الأمر أنها تجزم عل ا ائب، و ذللك افعل ا مجهول للمتكلم والمخاطب، نحو: لأكرم، و لتكرم يا زيد؛ لأن الأمر فيها للغائب وتقل في الفعل المبني للمعلوم، والثاني أقل؛ لأن له يغة خصده، وهي فعل الأمر فيستغنى بها عن اللامج(")

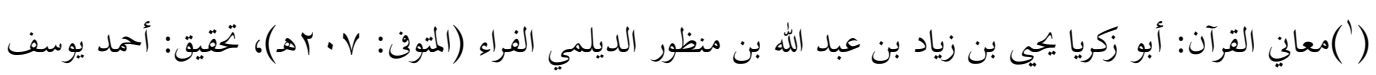

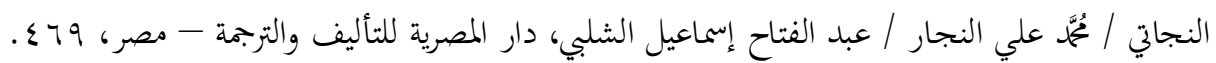

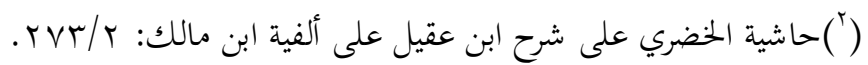


ـ إعراب القز آن: أبو جعفر النََّّاس أحمد بن محمد بن إسماعيل بن يونس المر ادي النحوي (المتوفى: ^بسهـ)، وضع حو اشيه و علق عليه: عبد المنعم خليل إبراهيم، منشور ات محمد علي بيضون، دار الكتب العلمية، بيروت، إYـ ا هـ. - إعر اب ما يثكل من ألفاظ الحديث النبوي: أبو البقاء عبد الله بن الحسين بن عبد الله العكبري البغدادي محب الدين

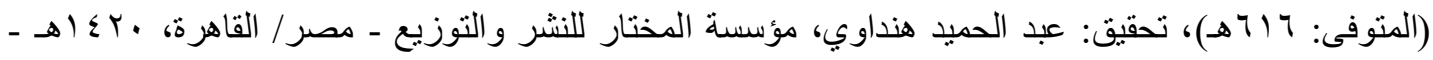

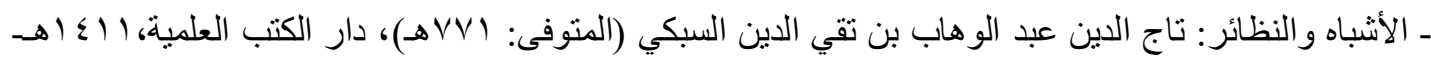

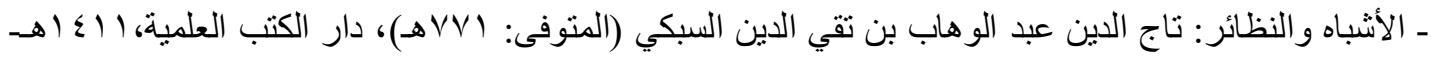

ـ الإنصاف في مسائل الخلاف بين النحويين: البصريين و الكوفيين: عبد الرحمن بن محمد بن عبيد الله الأنصاري، أبو

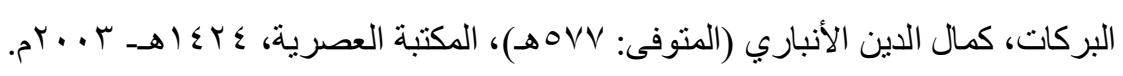

ـ الإنصاف في مسائل الخلاف لأبي البركات الأنباري ومعه كتاب الانتصاف على الإنصاف للشيخ محم محيي الدين عبدالحميد، طبعة: دار الطلائع.

ـ الكتاب لسيبويه: تحقيق وشرح: عبد السلام محم هارون، مكتبة الخانجي، القاهرة، الطبعة الر ابعة (7؟؟ اهـ ـ

$$
\cdot(5+\cdots)
$$

ـ اللمع في العربية: أبو الفتح عثمان بن جني الموصلي (المتوفى: بو جهـ)، تحقيق: فائز فارس، دار الكتب الثقافية

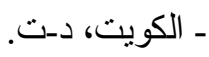


ــ المغني في تصريف الأفعال: محمّدُ بنُ عبد الخالقي بنِ عليّ بنِ عضيمةَ (المتوفى: بـــاهـ)، دار الحديثـ-

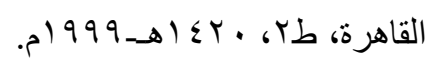

ـ المقتضب: محمد بن يزيد بن عبد الأكبر الثمالى الأزدي، أبو العباس، المعروف بالمبرد (المتوفى: 1 بـهـ)، تحقيق: مححد عبد الخالق عظيمة، بيروت، عالم الكتب. دـت. ـ المنهج الصوتي للأبنية العربية، عبد الصبور شاهين، دار الوفاء القاهرة، 9VV ام، ـ النشر في القراءات العشر: شمس الدين أبو الخير ابن الجزري، محمد بن محم بن يوسف (المتوفى : بrی هـ)، تحقيق: علي حمح الضباع (المتوفى • ـ1 1 هـ)، المطبعة التجارية الكبرى [تصوير دار الكتاب العلمية]. ـ أوضح المسالك الى ألفية ابن مالك ، لابن هشام الأنصاري ، تحقيق محم محي الدين عبد الحميد ، بيروت ، د.ت . -حاثشية الصبان على شرح الأشموني لألفية ابن مالك، لأبي العرفان ححم بن علي الصبان الثافعي، ط: ا، دار

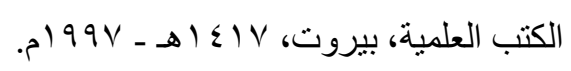

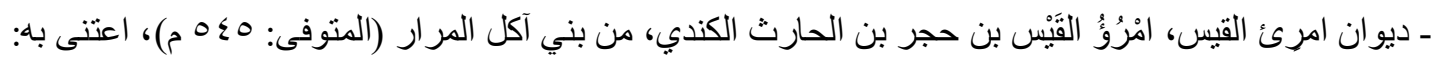

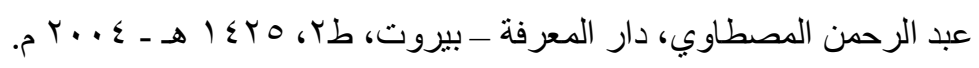

ـ سنن الترمذي: ححمد بن عيسى بن سَوْرة بن موسى بن الضحاك، الترمذي، أبو عيسى (المتوفى: YV9 هـ)، تحقيق

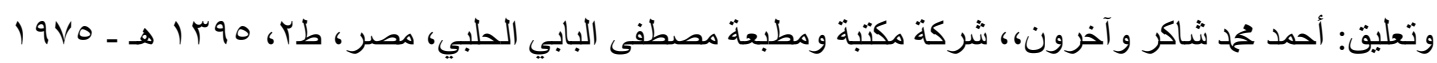

ـ شرح الرضي على الكافية: رضي الدين الأستراباذي، تصحيح وتعليق: يوسف حسن عمر الاستاذ بكلية اللغة العربية والدراسات الاسلامية كلية اللغة العربية و الدراسات الإسلامية، جميع حقوق الطبع محفوظة ه9 با ه ـ

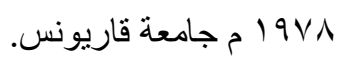

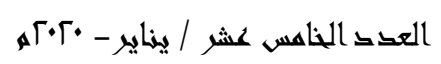


ـ شرح ألفية ابن مالك لابن الناظم ، تحقيق عبد الحميد السيد عبد الحميد ، دار الجيل ، بيروت ، ب.ت .

ـ شرح المفصل لابن يعيش: ت: الدكتور إبر اهيم محمد عبدالله، طبعة دار سعد الدين، الطبعة الأولى (؟بـ اهـ ـ

$$
\left(y^{2}+1\right)
$$

ـ علل النحو: ححمد بن عبد الله بن العباس، أبو الحسن، ابن الوراق (الكتوفى: (اNهـ)، تحقيق: محمود جاسم ححم

$$
\text { الدرويش، مكتبة الرشد ـ الرياض / السعودية، . بع 1 هـ ـ } 999 \text { ام. }
$$

ـ علم المعاني: عبد العزيز عتيق (المتوفى: جوبا هـ)، دار النهضة العربية للطباعة والنشر و التوزيع، بيروت ـ

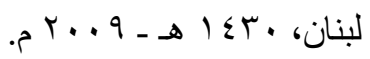

ـ مغني اللبيب عن كتب الأعاريب: عبد الله بن يوسف بن أحمد بن عبد الله ابن يوسف، أبو محح، جمال الدين، ابن هشام (المنوفى: (آVهـ)، المحقق: د. مازن المبارك / ححم علي حمد الله، دار الفكر ـ دمشق، ط7، 910 ام. ـ همع الهوامع: عبد الرحمن بن أبي بكر، جلال الدين السبوطي (المنوفى:

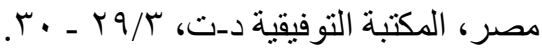

$$
\text { العقد الخاهس عشر / ينماير - •Г·م }
$$


بعد دراسة الجملة الفعلية وبعض مسائلها النحوية، انتهى البحث إلى بعض النتائج المهمة في الدرس النحوي،

- - أهمية دراسة الفعل في أزمنته المختلفة تؤدي إلى فضائيات في السياق التركيبي للجملة العربية .

- عدم اقتصار الفعل الماضي على الزمن فحس؛؛ بل اهتمامه بالو اقع " الحال "

- - تظل قيمة الفعل المضارع مجردًا من الأدوات الإضافية عليه ذا قيمة كبرى في السياق اللغوي .

- تنوع صور الفعل الأمري للالالة على تنوع صيغ التلقّي .

\begin{abstract}
$\underline{\text { Abstract: }}$
The study presents some grammatical issues of the actual sentence in different times, discusses the statements of ancient sculptors regarding each of the grammatical issues relevant to these ACTS, discussing these different opinions and weighting them in light of the sculptor's instrument. The study also shows the importance of action in its different times, which leads to different connotations in the structural context of the Arabic sentence.
\end{abstract}

Keywords: Statements, grammatical issues, the actual sentence, Different opinions of grammarians' linguistics points of views.

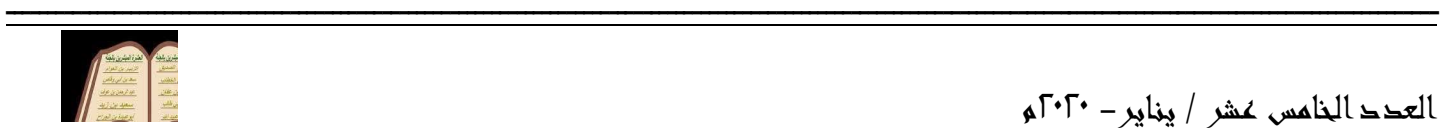

